\title{
Retraction Note to: Evaluation of air pollution and business English vocabulary translation in coastal cities based on distributed storage
}

\author{
Zhaowen $\mathrm{Cao}^{1}$
}

Published online: 3 November 2021

(c) Saudi Society for Geosciences 2021

Retraction Note to: Arabian Journal of Geosciences (2021) 14: 1815 https://doi.org/10.1007/s12517-021-08062-7

The Editor-in-Chief and the Publisher have retracted this article because the content of this article is nonsensical. The peer review process was not carried out in accordance with the Publisher's peer review policy. The author has not responded to correspondence regarding this retraction.

Publisher's note Springer Nature remains neutral with regard to jurisdictional claims in published maps and institutional affiliations.

The original article can be found online at https://doi.org/10.1007/ s12517-021-08062-7

Zhaowen Cao

czw13576980439@126.com

1 Foreign Languages College (International Education

College), Jiangxi University of Technology,

Nanchang 330098, Jiangxi, China 